Conference Paper

\title{
Biosorption of Total Chrome Metals on Leather Tannery Liquid Waste Using Tofu Dregs
}

\author{
Muhammad Aji Pangestu, Yahya Ardian Yuma Pracesa, Dyah Suci Perwitasari* \\ Chemical Engineering Department, Faculty of Engineering, Universitas Pembangunan Nasional "Veteran" \\ Surabaya, East Java, Indonesia
}

${ }^{*}$ Corresponding author:

E-mail: saridyah052gmail.com

\begin{abstract}
Chrome metal was the main element in tannery liquid waste. Chrome was included in B3 waste and has the potential to destructed or contaminated surroundings. The use of natural material as an adsorbent medium for b3 heavy metal currently was being studied. Tofu dregs were an alternative that can be used as biosorbent. This study's aim was to adsorbed total chrome metal in tannery liquid waste. The operating conditions took place at a $\mathrm{pH}$ of 7 and a stirring speed of $200 \mathrm{rpm}$. The analysis using Atomic Absorption Spectrometer (AAS) showed that the total chromium adsorption efficiency occurs in the addition of 6 grams of biosorbent with a contact time of 160 minutes. The adsorption percentage was $98 \%$ and the residual level total chromium metal in the tannery liquid waste was $0,33 \mathrm{mg} / \mathrm{L}$ after adsorption. These results have fulfilled the quality standard of the leather tannery wastewater that was allowed to be released into the environment with maximum total chrome metal levels of $0,5 \mathrm{mg} / \mathrm{L}$. The total chromium metal biosorption in this study followed the Langmuir isotherm and took place as chemisorption.
\end{abstract}

Keywords: biosorption, isotherm Langmuir, total chrome, tofu dregs

\section{Introduction}

The leather tanning industry is one of the industries that have a large amount of waste, namely in the form of solid, liquid, and gas. The waste comes from processed skin, materials for processing, and water. The waste from the skin is in the form of feathers, remains of meat, and pieces of skin, while the waste from processing materials is in the form of salt, lime, and other chemicals (Sugihartono, 2018). The wastewater from the leather tanning industry generally contains chromium metal which comes from a tanning process using a chromium sulfate compound between 60-70\%. However, in the tanning process, not all of the chromium sulfate solution is absorbed by the skin, so the rest is excreted in the form of liquid waste. The presence of high levels of chromium in the tannery liquid waste can cause environmental pollution and have a bad impact on health. Also, trivalent chrome waste will cause problems if it is oxidized to six valences (hexavalent) chromium ions which are toxic. (Ma'mun, et al 2016).

There are several methods for removing heavy metal ions from solutions consisting of physical, chemical, and biological methods. Conventional methods for removing toxic metal ions from solutions have been recommended, such as chemical precipitation, filtration, ion exchange, electrochemical treatment, membrane technology, coating, adsorption on activated carbon, evaporation, and photocatalysis (Gautam, et al 2014). Physical and chemical engineering requires high costs, a long process, and a lot of solvents so that it becomes a new problem in the exhaust system (Hevira, et al, 2019).

One of the biological methods in dealing with heavy metal chromium is biosorption. According to Michalak and Katarzyna, Biosorption is an adsorption process that uses biological materials

\section{How to cite:}

Pangestu, M. A., Pracesa, Y. A. Y., \& Perwitasari, D. S. (2020). Biosorption of total chrome metals on leather tannery liquid waste using tofu dregs. ${ }^{\text {st }}$ International Conference Eco-Innovation in Science, Engineering, and Technology. NST Proceedings. pages 200-204. doi: 10.11594/ nstp.2020.0531 
(biomaterials) as absorbers, where the ions in the solution will bind to the functional groups present in the biomaterial (Michalak \& Katarzyna 2013). The functional groups include carboxyl groups, carbonyl, hydroxyl, alcohols, amines, esters, sulfides, and others (Kampalanonwat, and Pit 2014). The sorbent used in this research comes from tofu dregs. The solid dregs from making tofu can be used as a biosorbent because it contains amino acids that can bind heavy metals. Previous research conducted by Nohong (2010) stated that tofu dregs biosorbent had the best adsorption capacity in total $\mathrm{Cr}$ and $\mathrm{Fe}$ in leachate by $100 \%$ and $95.53 \%$. Hartati, et al (2016) also conducted similar research, namely the adsorption of $\mathrm{Pb}$ metal in leachate with the best adsorption capacity of $98.03 \%$.

In Mawardi, et al (2014) research, namely the separation of $\mathrm{Cr}$ III and $\mathrm{Cr}$ VI ions with green algae biomass, optimum speed of $200 \mathrm{rpm}$ was obtained. The degree of acidity (pH) used in Wijaya \& Ita (2015) study, namely the adsorption of $\mathrm{Cd}^{2+}$ ions in a solution using activated carbon from tamarind seeds, obtained an optimum $\mathrm{pH}$ of 7 . The volume of $100 \mathrm{ml}$ of wastewater used in Nohong's (2010) study is the use of tofu dregs as an absorber of chromium, cadmium, and iron metals in leachate. The temperature used in Mariana, and Maulana (2013) study was the effect of temperature in removing $\mathrm{Cr}(\mathrm{VI})$ by using guava leaves as a biosorbent, the optimum temperature was $50{ }^{\circ} \mathrm{C}$. The particle size used in Hartati, et al (2016) study was the adsorption of $\mathrm{Pb}$ metal ions in leachate using tofu pulp with a size of 60 mesh. The variables of the length of contact and weight of biosorbent used in Nohong's (2010) study were the use of tofu dregs as an absorber for chromium, cadmium, and iron metals in leachate, but there were slight changes in the variable interval.

From the background of previous research, it is possible to use tofu dregs as a biosorbent because it contains amino acids that are expected to reduce the impact of tanning waste pollution in waters, especially total $\mathrm{Cr}$ metal. The method used in this research is AAS (Atomic Absorption Spectrophotometer).

\section{Research Method \\ Preparation of tofu dregs biosorbent}

As much as $1 \mathrm{~kg}$ of tofu dregs is dried with the help of sunlight. The dry tofu dregs are then put in an oven and heated at $60^{\circ} \mathrm{C}$. After drying in the blender then sieving so that you get a size of 60 mesh.

\section{Determination of optimal time and weight of total chromium metal biosorption}

A sample of $600 \mathrm{ml}$ of leather tanning waste was put into a beaker glass and then the $\mathrm{pH}$ was adjusted using $0.1 \mathrm{M} \mathrm{HCl}$ to reach $\mathrm{pH}$ 7. Furthermore, 1.2 tofu dregs were given to the wastewater 2,$4 ; 3,6 ; 4,8$; and 6 grams with variations in contact time 40; 70; 100; 130, and 160 minutes. The operating conditions took place at a temperature of $50{ }^{\circ} \mathrm{C}$ and a stirring speed of $200 \mathrm{rpm}$. The processed wastewater is filtered with filter paper to separate the filtrate from the absorbent. The filtrate was then analyzed for total metal content using an Atomic Absorption Spectrophotometer.

\section{Result and Discussion}

Based on Figure 1 shows that the correlation between the weight of the biosorbent and the adsorbed chromium content is directly proportional. Where the more biosorbents are added, the more total chromium is reduced. The largest reduced total chromium content is the addition of 6 grams of tofu pulp biosorbent. This is because the more biosorbents are added, the more active groups play a role in total chromium adsorption. 


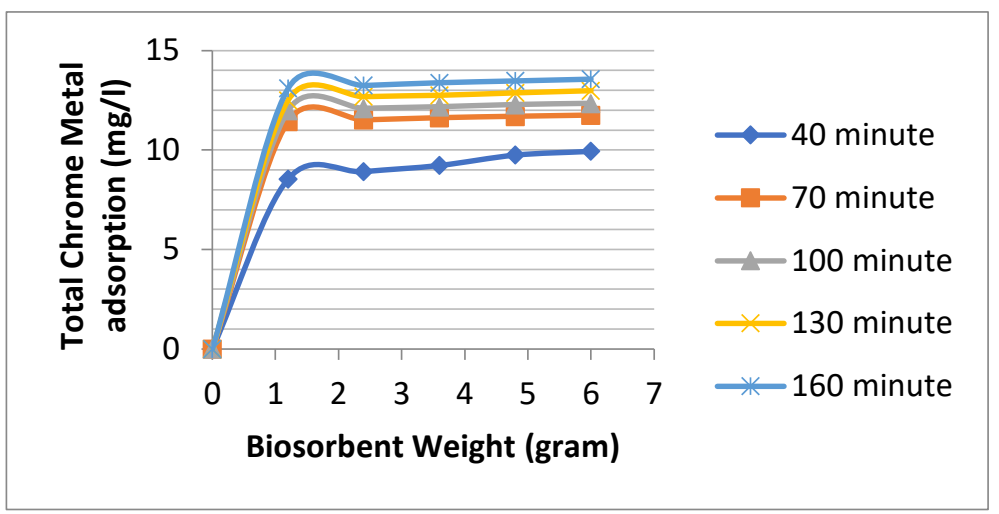

Figure 1. Effect of biosorbent weight on total chrome metal adsorption

In the Figure, it can be seen that the reduced total chromium with the addition of 1.2 grams of biosorbent for a time interval of 40 minutes, 70 minutes, 100 minutes, 130 minutes, and 160 minutes has a high increase in reducing power. This is because there are still a lot of total chromium levels in the waste and the effectiveness of the tofu dregs active group is still high. Whereas for the addition of 2.4 grams, 3.6 grams, 4.8 grams, and 6 grams of biosorbent, the increase in reduction was not too significant. This can be because the active side of the biosorbent starts to get saturated and also the total chromium content in the waste has been absorbed by the biosorbent.

Tofu dregs can be used as a biosorbent because tofu contains proteins that have the adsorption power of amino acids that form zwitterions. The metal adsorption mechanism carried out by the tofu dregs uses the ion exchange mechanism. Where the active groups in the tofu waste are carboxyl and amino groups. This functional group plays a role in the ion adsorption mechanism.

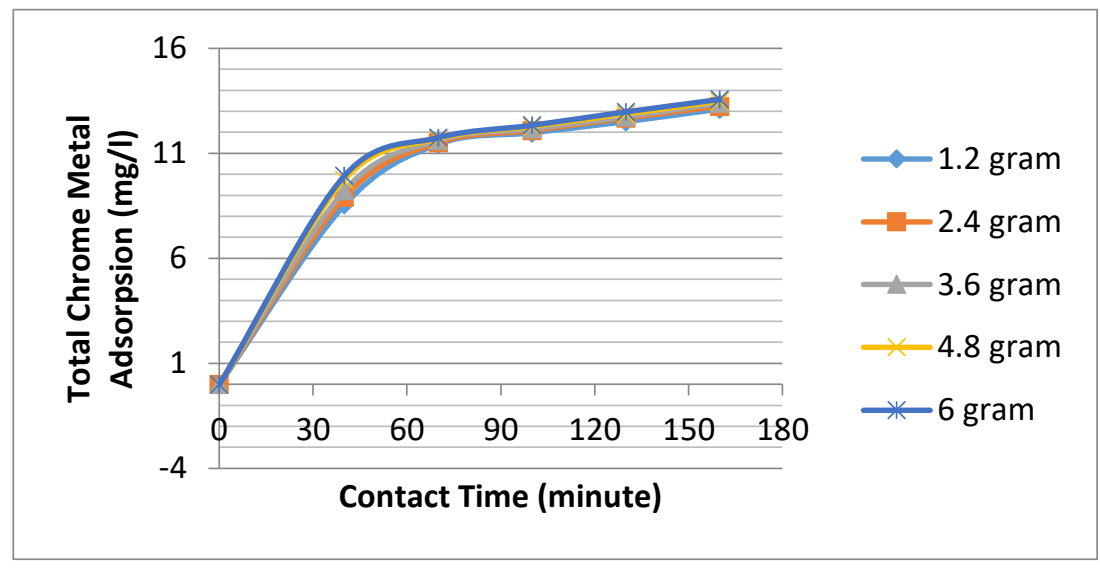

Figure 2. Effect of contact time on total chrome metal adsorption

Based on Figure 2 shows that the correlation between contact time and adsorbed chromium content is directly proportional. Where the longer the contact time that occurs, the more total chromium metal content is absorbed. The largest adsorbed total chromium content was at the contact time of 160 minutes. This is because at 160 minutes the active group on the biosorbent binds to the total chromium metal.

The Figure shows that the total chromium adsorbed at the contact time of 40 minutes and 70 minutes has a significant increase. This is because there are still a lot of total chromium levels in 
the waste and the effectiveness of the tofu dregs active group is still high. In contrast to the contact time of 100 minutes to 160 minutes, the biosorption process appears to have experienced a relatively constant increase. This shows that the active site of the biosorbent has been saturated by molecules and that a lot of the total chromium content in the waste has been absorbed by the biosorbent.

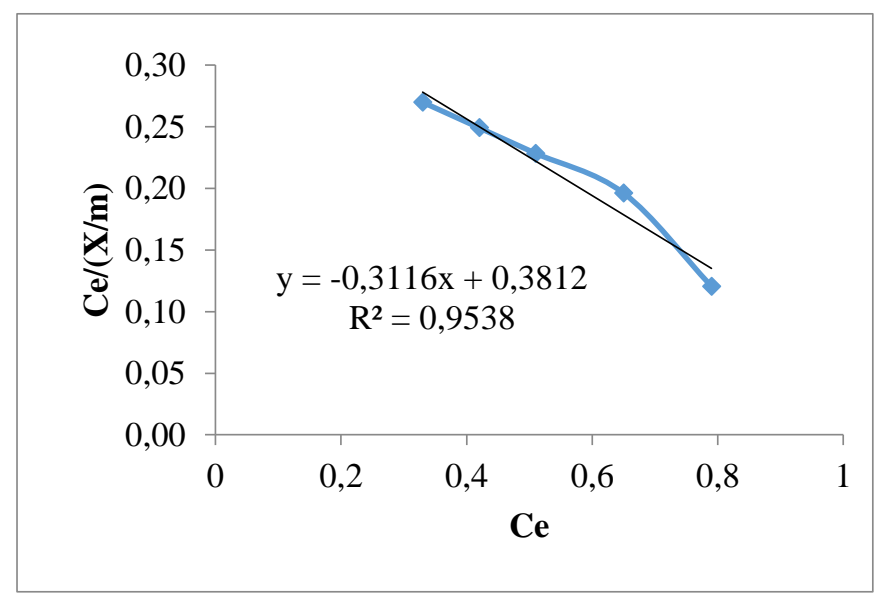

Figure 3. Langmuir adsorption isotherm

Figure 3 shows the total chromium metal biosorption process following the Langmuir isotherm. Where the Langmuir isotherm graph has a coefficient of determination $R 2 \geq 0.9$ (close to number 1) and takes place chemically (Wijayanti and Susatyo, 2018).

\section{Conclusion}

Tofu dregs can be used as a biosorbent to reduce heavy metal levels. The efficiency of total chromium adsorption by tofu dregs is $98 \%$. The optimum condition for total chromium adsorption is the addition of 6 grams of tofu dregs and the contact time is 160 minutes. Based on the results of the research and discussion of total chromium metal biosorption following the Langmuir isotherm, the Langmuir isotherm graph has a determination coefficient of $2 \geq 0.9$ and it can be concluded that the adsorption process takes place chemisorption.

\section{Acknowledgment}

This work was financially supported by Chemical Engineering Department, Faculty of Engineering, Universitas Pembangunan National “Veteran" Jawa Timur Surabaya 60294, Indonesia. Therefore, we are grateful for this funding and support of this research.

\section{References}

Gautam, R. K., Mudhoo, A., Lofrano, G., \& Chattopadhyaya, M. C. (2014). Biomass-derived biosorbents for metal ions sequestration: adsorbent modification and activation methods and adsorbent regeneration. Journal of Environmental Chemical Engineering, 2(1), 239-259. doi:10.1016/j.jece.2013.12.019

Hartati, S., Budianta, D., \& Hermansyah. (2016). Adsorption of lead content in leachate of sukawinatan landfill using solid waste of tofu. Sriwijaya Jurnal of Environment, 1(2), 42-43. doi.org/10.22135/sje.2016.1.2.42-46

Hevira, L., Zein, R., \& Munaf, E. (2019). Efisiensi penyerapan ion logam terhadap ph dan waktu kontak menggunakan cangkang ketapang. Jurnal Katalisator, 4(1), 43. doi: 10.22216/jk.v4i1.3358

Kampalanonwat, P., \& Supaphol, P. (2014). The study of competitive adsorption of heavy metal ions from aqueous solution by aminated polyacrylonitrile nanofiber mats. Energy Procedia, 56, 143. doi.org/10.1016/j.egypro.2014.07.142

Mariana, \& Maulana, F. (2013). The effect of temperature on Cr (VI) removal by using guava leaves as a biosorbent. Proceedings of The 3rd Annual International Conference Syiah Kuala University (AIC Unsyiah), 3(2), 128 
Ma'mun, S., Theresa, M., \& Alfimona, S. (2016). Penggunaan membran kitosan untuk menurunkan kadar logam krom pada limbah industri penyamakan kulit. Teknoin, 22(5), 367. doi.org/10.20885/teknoin.vol22.iss5.art6

Mawardi, Nazulis, Z., \& Kurniawati, D. (2014). Kajian Proses biosorpsi timbal (ii) oleh biomass alga spiroga subsalsa melalui modifikasi gugus karboksil dan karbonil. Bionatura-Jurnal Ilmu-ilmu Hayati dan Fisik, 16(2), 114-118

Michalak, I., Chojnacka, K., \& Witek-Krowiak, A. (2013). State of the art for the biosorption process-a review. Applied Biochemistry and Biotechnology, 170(6), 1389-1416. doi: 10.1007/s12010-013-0269-0

Nohong. (2010). Pemanfaatan limbah tahu sebagai bahan penyerap logam krom, kadmium dan besi dalam air lindi tpa. Jurnal Pembelajaran Sains, 6(2), 258

Sugihartono. (2018). Pemanfaatan limbah turunan industri penyamakan kulit sebagai upaya untuk meminimalisir dampak pencemaran lingkungan. Prociding Seminar Nasional Kulit, Karet dan Plastik, 7(1), 27

Wijaya, V. C., \& Ita, U. (2015). Pengaruh ph pada adsorpsi ion $\mathrm{cd}^{2+}$ dalam larutan menggunakan karbon aktif dari biji trembesi (Samanea saman). Jurnal Sains dan Seni ITS, 4(2), C88

Wijayanti, A., Susatyo, E., Sukarjo, S., \& Kurniawan, C. (2018). Adsorpsi logam Cr(VI) dan Cu(II) pada tanah dan pengaruh penambahan pupuk organik. Indonesian Journal of Chemical Science, 7(3), 246 